\title{
Raivolaa lukiessa
}

Reijo Raivola (2000). Tehoa vai laatua koulutukseen? Aikuiskasvatus-sarja. WS Bookwell Oy.

\section{Kasvatustieteen}

professori Reijo Raivola on kirjoittanut railakkaan ja raikkaan puheenvuoron koulutuksen laadun ja arvioinnin tilasta. Vaikka kirja on ilmestynyt pari vuotta sitten, sen anti on mitä ajankohtaisin edelleen.

\section{Raivola pohtii koulutuk-} sen koulutuksen ohjaukseen aiemman normi- ja resurssiohjauksen tilalle - tullutta informaatio- ja tulosohjausta. Hänen mielestään oppilaitosten tulosjohtamisen negatiivinen seuraus on reaktiivisuus: tehdään juuri sitä, mitä tiedetään arvioitavan ja tuloksiksi nostetaan se, mitä on helppo mitata. Tällöin seurauksena on hänen mukaansa pahimmillaan organisaation toiminnan "puuhasteluloukko" ja "paperiharjoituksiksi jääneet laatujärjestelmät”.

\section{Numeeristen arvojen}

pitäisi konstruktivistisen näkemyksen mukaan luoda kysymyksiä, eikä antaa vastauksia, sillä konstruktivistisen ajattelun mukaan mittaaminen luo merkityksiä. Mittarienkin taustalla on aina arvoja ja asenteita ja ne ovat kontekstiin sidottuja, joten niiden perusteella ei voi tehdä suoralta kädeltä objektiivisia arvioita, toteaa Raivola teoksessaan. Kuka mittarit ja tunnusluvut asettaa? Kenen arvoihin ja näkemyksiin ne perustuvat. Palvelu kuluu, ja Raivola poh- diskelee kirjassaan, miten voi mitata ja arvioida jo kulunutta palvelua, tässä tapauksessa opettamista ja oppimista.

\section{Kasvatuksen laatu olisi} nähtävä Raivolan mielestä transformaationa ja kehityksenä tai muodonmuutoksena, joka on laadullinen muutos. Se saadaan yksilössä aikaan silloin, kun kasvatus tajutaan kehitysprosessin tukemisena, kasvattamisena, valtauttamisena (empowerment). Tällöin kasvu yksilössä on tietojen ja taitojen sekä kykyjen muokkautumista osaamiseksi, jota ei voi mitata standardoiduilla testeillä. Kuitenkin osaamista on mitattu juuri sellaisilla seikoilla, joita on helppo mitata, mutta jotka eivät kerro ihmisen osaamisesta tai tiedon soveltamisesta arkitilanteessa, esimerkkinä yo-kokeet.

\section{Maahanmuuttajien,} koulutukseen osallistumattomien ja yhteiskunnan ulkopuolelle jääneiden tavoittaminen ovat Raivolan mielestä aikuiskoulutuksen todellisia indikaattoreita. Toisaalta käsitys koulutuksen kaikkivoipaisuudesta on tietoista politiikkaa valjastaa koulutus kaiken ratkaisuksi tai syntipukiksi. Sen sijaan suora puuttuminen sosiaalisiin ongelmiin, työttömyyteen, terveysongelmien todellisiin syihin ratkaisisi nämä ongelmat. Raivolan mukaan kyseessä olisi niin suuri vallan ja rakenteiden murros, ettei siihen uskalleta ryhtyä.

\section{Raivolan kirja on}

asiantunteva puheenvuoro ja ajatuksia herättävä pohdinta tilanteessa, jossa koulutuksen arviointi on lakisääteistä. Oppimisen vuorovaikutteisuus, prosessinomaisuus ja kognitiivisuus ovat asioita, joita ei ole juurikaan tutkittu samoin kuin luokan/opiskelijaryhmän sisäisiä prosesseja ja niiden vaikutusta oppimiseen. Tieto on taitoa ongelmanratkaisun kontekstissa, elävässä elämässä, arkipäivässä ja koulun ulkopuolella. Näitä arvioitaessa kyse on oppilaitoksen perustehtävästä ja koulutuksen vaikuttavuudesta.

\section{Anne Rosenius}

Aikuiskasvatus-lehti julkaisi Tehoa vai laatua-kirjasta Reijo Laukkasen arvion numerossa 3/2000. 